\title{
Djakarta's Forgetting
}

\author{
Aritha van Herk
}

\section{L'oubli de Djakarta}

Qui a la mémoire la plus longue? Le soldat roman s'annihile pour survivre au futur, pour se faire un martyr, une mémoire, un mythe, un moment de désespoir transfiguré. Djakarta, elle, perçoit la mémoire comme involuntaire, hésitante et erratique. Elle cherche à coder la mémoire, à oublier précisément pour que la mémoire revienne comme un visiteur imprévu. La mémoire s'oriente autour du plaisir ou de la douleur. Djakarta fait l'inventaire de son corps pour y tracer et revivre dans les cicatrices le texte de la douleur. Mais, ce qui lui échappe toujours c'est la mémoire de sa naissance ou de sa défiguration tracée dans la tache de naissance à la nuque cachée par ses cheveux - la cicatrice la plus mystérieuse.

Who has the longest memory, the slayers or the slain? Masada: when the zealots were defeated in their last stand against the Romans, death was transformed into a memory of victory. All those men drawing lots, the ten remaining having to kill their fellow defenders, all 960 of them. There was ritual to this dying, a method, speed. Did the bodies begin to pile up, or were they perfectly acquiescent, lined up in a row, willingly taking turns, falling neatly, their arms at last steady, their heads bowed. And then of those ten remaining, another drawing of lots, until one slew his fellow slayers before pushing his sword through his own body. For the last man, who had not only to kill those others but himself, was his own brief memory of aloneness enough to convince him that there was victory in defeat? This is mutilated memory, annihiliate the self in order to survive the future, to make a memory, and then a myth, a martyrdom, of defeat, a moment of despair become a triumph. Draw lots, toss a coin, throw a dice, pull a straw, all actions guaranteed to guarantee, to make a history of forgetting. And a field for action. Draw lots to be a volunteer for memory.

Djakarta sees memory as a reluctant volunteer: erratic, unwilling to come up with its hand, and certainly not at any predictable beck or call. 


\section{Djakarta's Forgetting · 77}

She codes how to remember: deliberately forget and the specific memoried moment will come back with a visitor's intent, the brief whiff, a smell or sound snagging the thread of an old moment. What should one remember? And Djakarta believes that the good, the benign, are almost always lost in the surplice of time.

To Djakarta memory is terra incognita; her drives to uncover her own resist location. She hunts through textbooks on the brain.

Where does the memory process take place in the brain?

Unknown.

Where is memory stored in the brain?

Unknown.

Memory's area everywhere, a spreading patch of spilled liquid. Electrical circuits, DNA, some chemical circuits, a soup of repetition?

Djakarta ties her memory to lostness. Losing her wallet, her comb, her watch, her losses are repetitious and tedious, entirely imbued with a carelessness that she does not place or wish to possess. And loss is its own memory; if she knew where something was it would not be lost, if she were aware of losing it, the loss would not occur. Once something is lost, it is impossible to remember how the loss occurred because if her memory had been present and activated, the loss would never have happened. So that lostness is its own oxymoron, once she realizes something is lost, its foundness is impossible, only possible by chance or good fortune, some mix of the superstitious there, and she knows that lostness is a weapon that has worked against women. Having lost their power and desire, how can they know what is gone, and how then can they recover it?

Lostness too late, too open to interpretation. If she knew what had happened to her keys, her earrings, they would not be lost, she would know where it was and how to find it. Then it wouldn't be lost, so lostness is a subset of not knowing, and this is the terrifying part for Djakarta: what she doesn't know that she doesn't know as she unknowingly proceeds. Where does memory reside when she stops looking at it and for it? Does it hide, keep itself transparent and available?

What does she remember? Has it all to do with pleasure or pain? She looks for memory on her body, on its oblivious but markable skin, the subtle touch of scars or their embrasures. Starting at the foot, her small broad feet, not delicate but pleasing in their symmetry, without the carpal bones, the simion toes that other feet display. She loves her feet, their flatness, their solidity, their habit of thumping without permission. 
Their langourous pleasure in being touched, that she can come when a lover rubs her feet, that her toes curl into shells of desire. Rotund toes, cushioned and unfibular, not marred or scraped by accident, although, and here memory does its quick flip, she remembers Marja's toes, mangled and bleeding, from being caught between the uncovered and unsafe spokes of the old black bicycle from Holland. Foolish, to put your foot in it. Try a finger first, less dangerous, more costly. Ride the turning wheel, but keep your feet clear, and she was barefoot too, lucky Marja whose mother did not insist on shoes. Yes, Djakarta is pleased with the sprouts, the phalanges of her toes, their vernacular promising the quick tenacity of every peasant foot. Comic, their stubbiness, inelegant, determined, full of balance. Attached to a foot that is without an arch, flat feet she has, a legacy of poor shoes as a child, and overwalking. This is not visibly memorable, no scar marks her fallen arches, but they memory themselves nevertheless, and she has only to walk a long way without proper shoes for the old ache to return, that ache she endured as a child for days and days, sometimes so deep under her arches that at night she could not sleep, and the fierce pain from her feet up to her legs terrible in its urgency. She would never be able to forget that hurt, continuous and brutal, so that she cried without weeping, cried for its relentless tenacity. Ongoing pain is enough of a hurtful claim, and for years, all she remembers are her feet hurting, lying in bed with her legs drawn up to her stomach and her feet caught in their own dull ache. But there is no mark to memorize that, no scar. Only the rather low curve of her foot and the chalky bottoms of her soles. She can check for scars there, lift her foot to her knee and turn it visible to her bent neck, but she finds only the patterns of skin, the tributaries of skin's printing.

On the sole of the left foot, however, there is a scar, a visible notch that compels her to remember, did she step on something? A sharp twig in the bush? A knife? Glass, yes, that was certainly it, broken glass on the floor, from, and here memory slides past Djakarta again, a dropped glass? A bowl? Some object thrown down in frustration or dropped, something that slipped through the fingers of claim and fragmented itself over the floor. Yes, that must be it, a wedding present, the cut-glass crystal bowl exploding into millions of fragments, and her bare feet there between the pieces of anger as easily tempted as the earlier tears that she practiced. She steps, carefully, on one of the smaller pieces, secretly, as if it will give her chance to retrieve it from her skin before the sting, before the blood, its red remarks on the floor, as she tries patiently, treading 
between the shards to sweep them into a semblance of clean up. And now the scar remembers, a dark notch right at the soft part before the fascia of the pad behind her toes. Perhaps there is still a shard of glass buried there, her foot craves its sharp piercing every once in a while, and she wonders, if her foot were boiled or baked as a dish, would the eater pick from between his teeth a sliver of that glass, embedded all these years in her sole. A foreign body, a splinter of glass.

To her ankles, Djakarta's peasant solidity is less reliable there. Despite the steadiness of her feet, her ankles are weak, again the poverty of bad shoes, of supersititious parents who would not let Djakarta run barefoot. Her ankles turn quickly, she has sprained them repeatedly over the years, stepping off a curb, getting up from a chair, dancing, even in the momentary joy of leaping from a step. Weak ankles, the skater's nightmare, and she lies on the floor turning them this way and that, trying to persuade them to be more resiliant, to have a longer memory of support. Her ligaments tear her from movement again and again, and she dreams of not having to hesitate over their ability, she dreams of ankles as tendoned as those of horses. She tore her right ankle ligament seriously once, but that too is unscarred, although certainly memoried. She simply put her foot down, off a step, and below the step's neatly grassed solidity, the treachery of a hole. Unprepared, her foot snapped over, and she was on the ground, unable to breathe from the pain, nauseous, the snap still audible behind her eyes, the very sound of her body breaking, while she lay gasping, pain riding every ridge. She can remember that step and snap, the ligament of her foot torn and the sick flood through her body, nausea, the instant shock, shivering into the steady pain that was iron hot by morning, so that she got into her own car, and drove a hundred kilometres, standard, clutching and shifting, her injured foot steady on the gas pedal into Edmonton. To Gys, who had set up an appointment with an orthopedist, who instantly immobilized her, put the ankle in a cast. And she couldn't drive, had to leave her car there, unable to move from one space to the next while the pain made her wild with rage. There are no scars for that memory either, although Djakarta can no longer look at her solid little feet without remembering with a rush of nausea that snap, the sound of the foot turning, her body in shock, shaking at its own damage.

We wait, so memoried are we, for objects to provide occasion, to swing us past momentary lapses of time. Djakarta rejects the photograph, its posed and poised notation of moment, the way that it insists 
on itself as record. The postures and squinted eyes that speak to a camera rather than to a recorded instant, or an action. She believes only in photographs of people taken when their backs are turned. Then she hovers over the shadowed paper trying to see their engagement with the task at hand, the shoes being cobbled, the horse fighting under the bridle hand.

Her own body will not hold itself still for her to check its engagement. She wants to watch herself living from the back, behind herself, watch her own gestures when she is not watching, so that she can see the engagements that she closes upon, the reconciliations of her limbs and her posture. There are scars she has never seen, even with the judicious arrangement of a mirror or by twisting herself into a contorted angle of observation. She tries to see the thin tear on her upper calf behind her left knee, Djakarta wobbling on the bike down the lane, and Gys holding her up, running behind, until she was free and away, flying two-wheeled into dirt wind, and so breathless that the handles under her gripped palms turned themselves and she skidded into the barbed wire fence beside the lane, its rusty promotion implacable against her skin, tearing the back of her leg as the skeleton bicycle and the girl landed together in the ditch, stopped altogether. Stitches, Djakarta recalls, yes, it took stitches, but she cannot remember getting them, she can only remember the heady moment when she and the bike took flight together just before they met the earth again.

Although she remembers the other stitches, from her hand slammed in the porch door, running into the house to get a pear, that was it, her hurry to taste the delicious grain of fruit so foreign to Alberta, running from the outside to the inside and slamming the door on herself, on her own hand, so that the top of her middle finger was sliced away between the edge and the frame and her hand went into its own shock, refused to be a hand and became a claw, a metal fork full of lightning. The blood was a relief, washing down her skirt, as if her skin could be held accountable, as if it dared to tell itself it could be damaged. Vlak held her with curious tenderness in the car the twenty-five kilometres to the doctor, as if Djakarta might be testing her own pain and mortality, but once the doctor's steel-eyed tally had estimated only minimal damage, Vlak returned to herself, and told Djakarta not to cry over such a small thing, the needle, the swabbing, the stitches, the bandaging, so that Djakarta's finger resembled a huffy mummy between the intelligence of the others, 


\section{Djakarta's Forgetting · 81}

unfettered in their digital freedom. And then Vlak had to find Hastig at the auction market, to parade her shock and the white intensity of Djakarta's bandage, the speeding car ride into town with Piet. Among the hay and the snuffling of the animals waiting to be sold, the auctioneer's endless erasure of words, Djakarta held her finger stiff and tried to eat a hot dog with her left hand, wondering how it would look when the bandages came off and the real damage could be seen. That finger is still sensitive to the cold, and the top is flat, the nail oblong and out of line with the elegant shape of the others.

The tip of a finger gone in a door's quick closure, but that is her masturbating finger, its patient capacity for pleasure ten times the others. How to explain its extra dexterity? To its accident, its memory of hurt so long-handed that it insists on providing orgasm, the pain/pleasure of a body brought to stress? Perhaps its erotic capacity has nothing to do with its accident, but with its location. It is Djakarta's writing finger, the left side has a swollen bulb from years of clutching a nibbed pen at her sidewalk stand, drawing again and again those letters, the calligraphic memento a substitution for memory.

On the other hand - she is right-handed, no lefted mysteriousness to her - is a v-shaped scar from another door, this time a car door that she slammed on herself when a lover left her to go back to an earlier and more malleable woman, her anger at him turning on her body, and how could that have been accidental, shutting the door on her own hand, as if the metal trap of the man's love were equal to his car, a Mustang, she can remember that, as well as the smooth leather of the seat under her bareskin. The action had distracted her from the pain of his enunciation, his doubling back. Djakarta bent beside the car holding her hand with her hand, both hands alone again and in pain, even though he wasn't worth that much labour, even though he stood beside her stiff with recalcitrance, still necessary to get past the sunderment, the tearing. She can linger over that scar easily, its wishbone fork a reiteration of her aloneness and its discontent, her determined contentment with her freedom. She is merely observing her own hands, then, their various knife nicks and splinters, the longer genetic memory of her fingers' whorls coding her Djakarta, Djakarta, only Djakarta composed impossibly of the memories of Vlak and Hastig. The future and its reversions.

Yet, she does try to see with different mirrors and their angles her oldest and most mysterious mark, so that she can read its memory too. 
But that scar is impossible, only available to the most observant of her lovers, those who can discover that she comes when her neck is kissed, the back of her neck erotically charged with its old bent contrariness, Djakarta never face to face, but always reversed, and the birthmark right under the edge of her hair at the nape of her neck is the longest memoried mark on her body, it harbours her rubbed and runaway edge past all possible interpretation, and there, there, in its secret configurement under the line of her mousey hair, hides like a soul in waiting.

The birthmark waits for Djakarta to discover its memory, of birth or her own disfigurement, of the memories of her blood. And Djakarta too waits for its secret message to be discovered and lingered over, read at last. If memory permits, she will then be given back her memories, now cramped in the space of her body, and marked only by scars, their secret traces ledges, resting stops for climbers. 